\title{
MENYAKSIKAN MASA LALU MELALUI BIOPIC FILM DALAM KAJIAN HISTORIOGRAFI VISUAL
}

\author{
Sandy Allifiansyah \\ Universitas Bunda Mulia \\ Alamat surel: sandyallifiansyah@gmail.com
}

\begin{abstract}
Historical text from now on could be see in a visual form. Along with the technology, the interpretation about the past and its prominent figures become more plural. The audiences have been served the visual historiography (historiopothy) when they watched the biopic or any other historical movies. This visual historiography has a strong and weakness sides. On the positive side, we can see how the historical text is getting more fluid. There is no monopoly on the systematic historiography and single interpretation about what happened in the past. But another problem comes form on the other side about the competence and subjectivity of the historical author themselves.
\end{abstract}

Keywords: discourse, narration, postmodernism, visual historiography

\begin{abstract}
Abstrak
Teks sejarah kini bisa disaksikan dalam wujud paling mutakhir secara visual. Lewat kecanggihan teknologi, interpretasi kesejarahan tentang tokoh dan peristiwa masa lalu menjadi kian canggih dan beragam. Khalayak disajikan sebuah historiografi visual (historiopothy) melalui sajian biopic atau film bertema kesejarahan lainnya. Sajian visualisasi sejarah ini menyisakan keunggulan dan kelemahannya masing-masing. Di satu sisi, teks kesejarahan menjadi cair, sehingga menggugurkan prinsip monopoli sistematika sekaligus pemaknaan akan peristiwa masa lalu. Akan tetapi di sisi lain, persoalan mengenai kompetensi sang pembuat teks (authorship) dari sebuah historiografi menjadi kian renggang sehingga timbul pertanyaan soal subjektifitas.
\end{abstract}

Kata kunci: historiografi visual, narasi, posmoderenisme, wacana

\section{PENDAHULUAN}

\section{Latar Belakang}

Dahulu kala ketika media untuk menulis masih sangat terbatas, orang-orang yang ingin merumuskan wacana peradaban zamannya, menggunakan medium prasasti dan dinding-dinding gua. Ratusan tahun kemudian, anak cucu mereka membaca teksteks yang ada pada prasasti dan dindingdinding gua tadi untuk memahami sistem sosial dan sistem moral yang mengikat masyarakat pada saat itu. Pada era selanjutnya, dokumentasi masa lalu mulai disebar luaskan pada lembar-lembar daun dan kertas. Di Indonesia, teks-teks tentang silsilah kerajaan-kerajaan Nusantara disusun rapi pada kitab Negarakretagama, Pararaton, bahkan Babat Tanah Jawi.

Memasuki era kemerdekaan, buku masih dipakai untuk merumuskan gagasan kemerdekaan. Tokoh-tokoh seperti Soekarno, Hatta, dan Tan Malaka menggelora dalam kata-kata demi impian
Indonesia merdeka. Masa setelah kemerdekaan, teks-teks sejarah tidak lagi muncul dalam bentuk tertulis, melainkan muncul pula dalam wujud visual. Terdapat dua era untuk menandakan era visualisasi sejarah di Indonesia. Pertama saat masa Orde Baru ketika rezim militer berkuasa, teks sejarah dimonopoli dalam wacana heroisme militer yang terwujud dalam filmfilm seperti Penghianatan G30S/PKI (1984), Janur Kuning (1982), hingga Serangan Fajar (1979). Contoh-contoh bagaimana film-film sejarah adalah perpanjangan tangan dari propaganda rezim. Film-film berlatar belakang sejarah yang diproduksi di bawah rezim Orde Baru sangat kuat diwarnai oleh persaingan ideologis antara sipil dan militer, di mana peran militer ditonjolkan sebagai pihak yang paling berjasa bagi bangsa (Irawanto, 1999, h. 6-7).

Era kedua adalah saat Reformasi ketika teks-teks sejarah lewat sajian visual tidak lagi dimonopoli oleh pihak militer. Fakta lain tentang perfilman Indonesia pasca 
Orde Baru adalah munculnya berbagai film dokumenter termasuk kesaksian sejarah dan sosial politik yang didanani oleh NGO (Nugroho \& Herlina, 2015, h. 250). Dengan demikian semakin banyak pula tercipta tafsir akan sejarah sekaligus penulisan ulang dari sejarah Indonesia kontemporer via medium film. Salah satu contoh film bertema sejarah paling menggegerkan pasca Orde Baru adalah film The Act of Killing (2012) yang disutradarai oleh Joshua Oppenheimer.

Ilmu komunikasi sebagai salah satu cabang ilmu sosial yang mengkaji teks dan media memandang fenomena pergeseran cara penulisan historiografi dari tertulis menuju visual sebagai pergeseran dari kecenderungan gaya penyajian ala cara berpikir moderen yang serba kaku rigid, dan serba ter-standardisasi, menjadi makin renggang dan plural layaknya tradisi berpikir posmoderen.

\section{Historiografi Visual sebagai Produk Teks Posmoderen}

Terdapat dua pendekatan yang lazim digunakan dalam metode penulisan sejarah atau historiografi. Pertama adalah historiografi naratif, yaitu jenis penulisan sejarah yang berisi tentang rekaman kronologis peristiwa politik dramatis (Zed, 2001, h. 3). Pendekatan semacam ini adalah gaya penulisan sejarah paling konvensional. Kesejarahan yang ditulis dengan gaya naratif menekankan pada epos kepahlawanan yang didasari pada satu sudut pandang. Tak jarang pula cara penulisan sejarah semacam ini akan membentuk pola oposisi biner dengan mengkontraskan dua kutub yang saling bertentangan satu sama lain. Alur narasi dalam sejarah manusia juga diceritakan bergerak karena adanya konflik dan pertentangan antar oposisi biner (Deliege, 2004, h. 30).

Kedua adalah historiografi strukturalis, yakni jenis penulisan sejarah yang berisi tentang eksplanasi sosial yang menekankan pengaruh dari struktur terhadap masyarakat dan segala dialektikanya (Alian, 2012). Gaya penulisan struktural ini dipelopori oleh kelompok sejarawan Les Annales. Di Indonesia sendiri, gaya penulisan historiografi mengalami sebuah pembaharuan saat Sartono Kartodirjo menulis sejarah tentang pemberontakan petani Banten 1888. Sartono memberikan sudut pandang dan pendekatan baru terkait historiografi. Pendekatan histriografi ini dikenal sebagai pendekatan multiinterpretability atau pendekatan multidimensional (Kartodirdjo,1983).

Historiografi Indonesia mengalami fase pribumisasi sejak 1957 saat diselenggarakannya Seminar Sejarah Nasional Indonesia Pertama di Yogyakarta. Setelah itu kegiatan ragam penulisan sejarah menjadi sebuah keniscayaan (Kuntowijoyo, 2003, h. 1-3) dan ditulis ke dalam berbagai bentuk juga jenis ruang lingkup. Misalnya sejarah tentang kemiliteran, sejarah lisan, hingga sejarah populer. Istilah teks populer sebenarnya adalah pintu masuk untuk memulai petualangan teks posmoderen di dunia kajian ilmiah.

Kini, dunia ilmu sosial telah mengalami pergeseran menuju sebuah arah tradisi pemikiran baru atau yang sering disebut sebagai posmoderen atau pascamoderen. Posmodernisme adalah penolakan terhadap cara pandang dunia yang kaku, penuh standar, dan saling klaim satu sama lain mengenai disiplin keilmuan (Barker, 2004, h. 156). Dalam kerangka perspektif posmodernism, jarak dan batas tersebut menjadi kabur. Artinya batasan antar ilmu, ilmiah atau tidak ilmiah, topiktopik kontroversial dan alternatif seperti fantasi, gay, lesbian, dan kelompok menyimpang lainnya, menjadi sah dibicarakan (Seidman, 1994, h. 2). Perspektif posmodernisme memungkinkan kita untuk membuat formula baru tentang dunia dan segala aktifitasnya. Adanya liberalisasi pemikiran yang dibawa oleh cara berpikir posmodern, berpengaruh juga dalam pluralisasi teks-teks populer, termasuk pada teks dan narasi yang membahas tentang peristiwa-peristiwa di masa lampau.

Historiografi juga ikut mengalami pembaharuan saat munculnya cara pandang posmodernisme ini. Inti dari penulisan historiografi dalam kerangka berpikir posmodern adalah dekonstruksi dan penggabungan antara imajinasi dengan wacana zaman guna memahami konteks zaman, sekaligus guna menulis ulang sejarah dengan cara yang baru (Jenkins, 2003, h. 
79). Jenkins menambahkan bahwa terdapat dua cara dalam memahami sejarah dalam kerangka posmodern (2003, h. 82-83) terutama bila mengacu pada manifestasi teks-teksnya pada media. Pertama, sejarah adalah sebuah refleksi soal mengapa fragmen sejarah itu yang dihadirkan kepada publik, dan mengapa dengan cara yang demikian sejarah itu ditulis ulang. Kedua, melakukan refleksi skeptis terhadap penulisan dan fragmen sejarah yang selama ini dianggap penting.

Cara berpikir posmodernisme yang diaplikasikan dalam narasi sejarah menekankan pada aspek pemaknaan atau interpretasi. Itu artinya, setiap orang yang mencoba untuk menulis sejarah dalam berbagai bentuk medium populer seperti film, novel, maupun artikel koran, mempunyai hak penuh untuk menyusun plot masa lalu tanpa mengikuti metode dan klaim ketat layaknya sejarawan profesional. Gaya penulisan sejarah khas posmodern adalah bentuk keprihatinan sekaligus kritik seperti yang dilontarkan Hayden White bahwa seluruh historiografi adalah ironis, karena berisi paradoks terhadap realitas (White, 1974, h. 37), maka dari itu butuh dekonstruksi untuk menemukan fakta-fakta dan pemahaman baru akan sebuah historiografi.

Dengan menggunakan pemikiran historiografi yang berdasar pada teks audiovisual tersebut, maka aspek-aspek seperti sequences, pengambilan gambar, editing, dan lain sebagainya, menjadi perhatian khusus. Hal ini disebabkan bahwa pada aspek-aspek tersebut kita bisa menyaksikan kesejarahan yang dihadirkan kembali lewat medium layar visual. Kritik yang dilontarkan para sejarawan terhadap perspektif historiografi visual atau historiopothy adalah mengenai subjektifitas sang pembuat film yang rentan mendistorsi sejarah. Belum lagi fakta-fakta trivia imajiner yang tidak dapat dipertanggung jawabkan (Beau, 1997). Akan tetapi, pendapat ini dibantah oleh pemikir posmodern yang mengemukakan bahwa penulisan sejarah secara rigid pasti tidak lepas pula dari subjektifitas dan distorsi sejarah. Contoh kasus paling mudah untuk melacak maksud dari klaim ini adalah produk sejarah yang ditulis oleh Orde Baru yang militer sentris. Oleh karena itulah para posmodernis menawarkan cara pandang baru yang menyatukan subjektifitas, fantasi, sekaligus argumentasi yang dapat dipertanggungjawabkan dalam menginterpretasikan sejarah lewat medium apapun, termasuk film dan lain sebagainya.

Film-film bertema kesejarahan yang muncul pasca Orde Baru dengan tema dan genre menjadi bukti adalah pluralisme dan keinginan untuk menulis ulang sejarah dari beragam sudut pandang dan subjektifitas. Film Gie (2005), Di Balik 98 (2015), Soegija (2012), Sang Kiai (2013) dan lain sebagainya. Masing-masing film yang disebutkan tadi, mencuplik dan menyuguhkan peristiwa kesejarahan maupun tokoh sejarah yang beragam latar belakangnya. Dalam narasinya bisa kita temukan fragmen-fragmen peran mereka dalam kesejarahan tanah air. Sesuatu yang sulit kita dapatkan di masa Orde Baru.

\section{Sejarah dan Pop Science}

Historiografi yang divisualisasi telah lama menjadi perhatian seorang Hayden White dengan menyebut fenomena ini sebagai "historiopothy" (1988). Terdapat pertentangan antar pemerhati sejarah mengenai akurasi sebuah historiografi yang ditampilkan secara visual. Konsep historiopohty menurut Rosenstone (2002) mendistorsi masa lalu yang menulikannya secara sembarangan.

Argumen Rosenstone itu berdasar pada fakta bahwa para sutradara penggarap film bukanlah sebuah orang-orang yang berprofesi sebagai sejarawan profesional yang bekerja di institusi ilmuah seperti universitas. Meskipun demikian, faktanya, generasi muda kerap merasa bosan saat mebaca buku-buku sejarah yang ditulis oleh para sejarwan yang mengklaim dirinya seorang profesional. Generasi muda menganggap bahwa bahasa yang digunakan terlampau ilmiah dan sulit dimengerti oleh awam. Terlebih lagi bila kita sebagai kaum awam tidak menemukan gambar atau ilustrasi tentang peristiwa tertentu di masa lalu. Hal semacam inilah yang selama ini menjadi kendala perkembangan sejarah sebagai sebuah ilmu pengetahuan di masyarakat. 
Sedangkan film sebagai sebuah medium untuk menulis ulang masa lalu memiliki kemampuan untuk melakukan visualisasi terhadap sosok-sosok historis, panorama masa lalu, hingga gaya berpakaian di kala itu. Mengacu pada sudut pandang keilmuan cultural studies, terdapat empat kuadran yang menerangkan posisi ilmu pengetahuan beserta perkembangan di tengah-tengah kehidupan masyarakat umum.

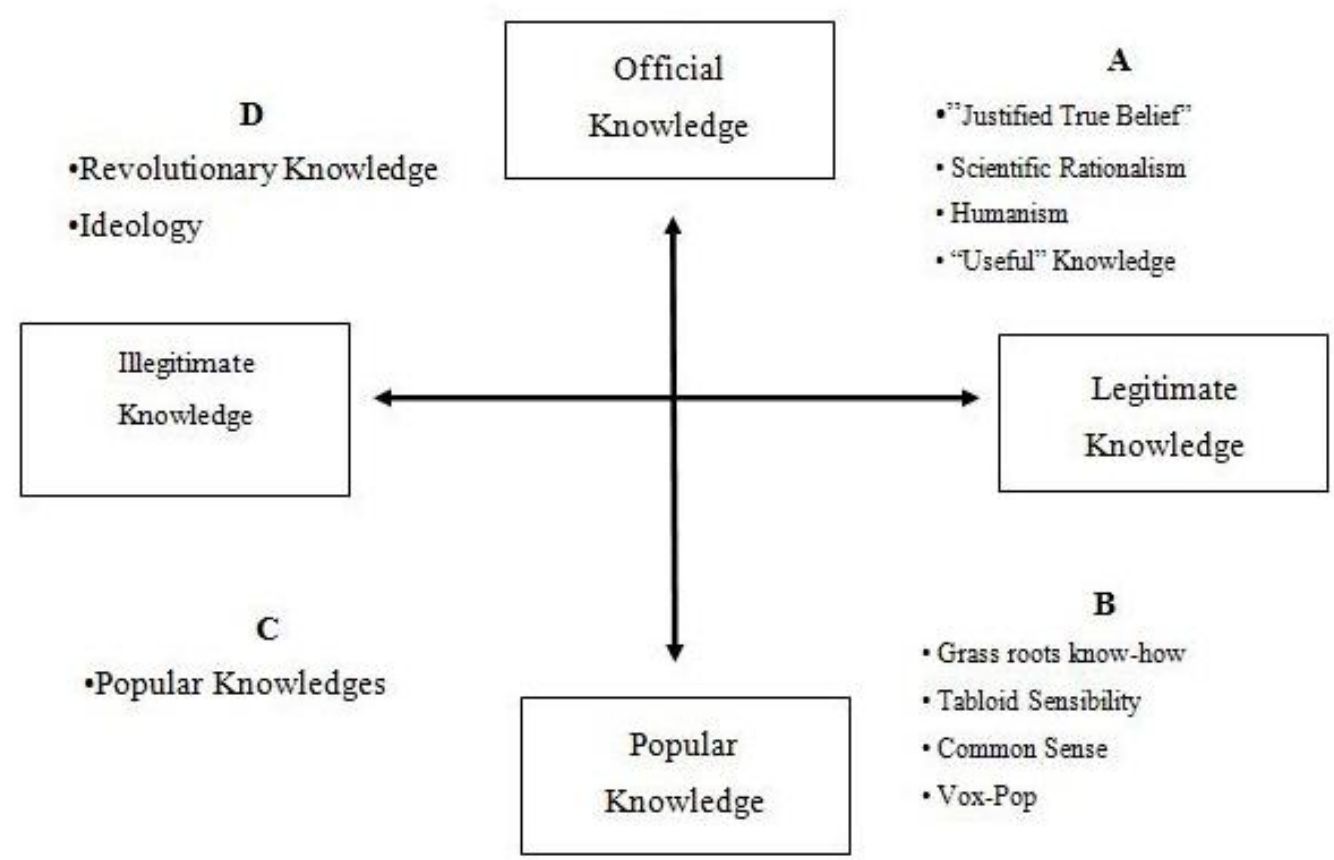

Sumber: Ilmu Pengetahuan/Knowledge-Scape (Birchall, 2006, h. 2)

Gambar 1: Empat Kuadran

Bagan dari Clare Birchall di atas menunjukkan bahwa terdapat empat kuadran pengetahuan, berikut posisinya dalam masyarakat. Ada sebuah pengetahuan yang sudah masuk atau dianggap kategori official terlegitimasi, misalnya postulat tentang matahari terbit dari timur dan perjumlahan dan pengurangan dalam matematika $(1+1=$ 2). Ada pula pengetahuan yang terlegitimasi dan bersifat populer di kalangan masyarakat. Contohnya tips-tips dalam memasak atau fakta-fakta sifatnya trivia di kalangan masyarakat umum. Fakta-fakta seperti $\mathrm{H}$. Agus Salim menguasai banyak bahasa atau Hindia-Belanda pernah berlaga di Piala Dunia 1938, termasuk dalam kategori ini.

Dalam dua kuadran lain, kita bisa menemukan bahwa ada pula pengetahuan yang masuk dalam kategori official tetapi tidak terligitimasi. Contohnya adalah ideologi yang sifatnya tertutup dan hanya dipahami dan diyakini oleh segelintir orang saja. Ada pula rumus-rumus atau paradigma baru dalam berbagai bidang ilmu pengetahuan yang sifatnya revolusioner tetapi belum diakui secara sah oleh pihak yang berwenang melakukan legitimasi, misalnya otoritas negara dan lain sebagainya. Kuadran terakhir adalah pengetahuan populer yang tidak mendapatkan legitimasi. Contoh nyata dari kuadran ini adalah isu-isu seputar jaringan korupsi di Indonesia atau desas-desus tentang siapa dalang dari peristiwa 1965.

Sejarah sendiri sebagai sebuah ilmu pengetahuan kerap menimbulkan polemik soal siapa yang berhak menarasikannya kepada publik. Kata "siapa" mengacu pada seseorang atau sebuah kelompok yang memiliki legitimasi untuk menuliskan masa 
lalu. Kuntowijoyo (2003, h. 15) sebagai seorang sejarawan pernah berujar bahwa ilmu sejarah perlu mengalami popularisasi dan sifat dari teks sejarah harus terbuka akan setiap interpretasi. Mereka yang bekerja di insitusi ilmiah seperti universitas atau pusat studi sejarah, tidak bisa mengklaim dirinya atau kelompoknya saja yang berhak menuliskan masa lalu. Bagi Kuntowijoyo, sejarawan adalah mereka yang menulis ulang masa lalu. Tidak peduli apa latar belakang profesinya.

Film bertema sejarah adalah medium yang efektif untuk melakukan popularisasi ilmu sejarah dan historiografi. Akan lebih menyenangakan pula bila kita bisa menyaksikan tubuh-tubuh masa lalu dimunculkan kembali dalam balutan aktor dan aktris abad 21. Kekuatan selebritis dan artis ini menjadi nilai lebih dalam rangka menyebarluaskan narasi masa lalu kepada publik. Dalam diri selebritis tertanam nilainilai ideal tentang kecantikan, kekayaan, dan ketenaran. Para artis ini juga memiliki kemampuan memikat hati dan perhatian jutaan pasang mata. Selebritis adalah hasrat kolektif masyarakat (Rojek, 2001, h. 186187). Dengan serangkaian fakta-fakta tersebut, tidak mengerankan bila industri tekevisi dan film menggunakan selebritis dan publik figur sebagai pekerja mereka.

Meskipun terdapat percampuran antara fakta historis dan imajiner, hal itu tetap dapat dipahamai sebagai cara industri populer seperti film mengemas produknya. Unsur-unsur seperti dramatisasi, humor, dan trivia (Storey,2008) adalah formula yang lazim ditemui agar audiens dengan mudah menerima maksud dari jalan cerita masa lalu yang divisualkan.

\section{Sejarah yang Ditubuhkan}

Masa lalu yang diwujudkan kembali dalam bentuk ilustrasi visual memungkinkan kita untuk mendapatkan gambaran tentang masa lalu secara lebih aktual. Hal ini terjadi karena masa lalu yang divisualkan adalah hasil dari serangkaian produk industri populer yang tidak selalu dilihat sebagai produk hiburan semata. Daya jangkaunya yang luas, narasinya yang mudah dipahami, hingga daya pikat yang para aktor/aktris yang berperan di dalamnya, mampu memberikan kesan tersendiri di benak khalayak.

Film maupun serial televisi bertema sejarah adalah medium untuk mewujudkan visualisasi sejarah. Perpaduan antara aspek audio dan visual menghasilkan sebuah kenikmatan kepada khalayaknya di setiap detik narasi yang disajikan. Realitas yang direpresentasikan dalam wujud visual ini, adalah bagian dari serangkaian sejarah panjang dari era kebudayaan moderen menuju posmodern (Batchen, 1996).

Selama perkembangan industri hiburan Indonesia, tubuh-tubuh yang dihadirkan dalam film bertema sejarah misalnya biopic, akan selalu berbanding lurus dengan popularitas sang aktor/aktris. Kita bisa melihat bagaimana Christine Hakim yang tengah tenar pada medio 80 -an, berperan apik sebagai Tjoet Nyak Dien di film biopic kolosal karya Eros Djarot. Tokoh yang berperan sebagai pemeran utama, berada dalam posisi body-double atau sebisa mungkin mendekati sang tokoh utama. Ini merupakan tantangan tersendiri bagi para sutradara, sineas, maupun aktor/aktris yang akan terlibat. Mereka tentunya harus membaca biografi tentang tokoh sejarah yang akan mereka perankan, bahkan membaca literatur-literatur sejarah yang menyangkut kehidupan sang tokoh.

Dalam studi yang menyangkut kaitan antara teks sejarah populer, tubuhtubuh historis yang ditampilkan kembali dalam wujud aktor/aktris populer adalah bagian dari strategi industri. Mereka melakukan taktik dengan mengutamakan aspek prominence yang dimiliki oleh sang aktor/aktris. Willem Hesling (2001) menyebut kecenderungan ini sebagai physiognomy atau firasat yang mengakar kuat dalam khalayak dalam diri seorang seniman layar lebar yang sering kita sebut sebagai aktor/aktris. Para seniman layar lebar ini adalah referensi yang dimiliki khalayak saat menyaksikan film-film populer.

Selanjutnya adalah manifestasi unsur pengejawantahan (embodiment) yang nampak pada tokoh utama. Penubuhan sejarah ini membantu kita untuk mengidentifikasi bagaimana sang tokoh utama secara sosial dan politik coba untuk 
dihadirkan kembali setelah sebelumnya hanya bisa kita lihat sosoknya secara visual di buku-buku sejarah. Aspek penubuhan menjadi salah satu isu utama dalam film bergenre biopic, sebab aspek penubuhan ini dapat mengkonstruksi pemahaman publik (Custen,1992) tentang tokoh tersebut pada zaman saat ia bernaung.

Penubuhan sejarah yang terwujud dalam visualisasi layar kaca, selalu akan menuai beragam tanggapan dari berbagai pihak soal subjektifitas. Kendati demikian, di era informasi seperti saat ini, budaya visual (visual culture) telah menjadi bagian dari kehidupan sehari-hari masyarakat. Rendahnya minat baca masyarakat Indonesia menjadikan medium film maupun tayangan serial televisi yang khusus membahas peristiwa masa lalu, menjadi jawaban jitu. Sejarah sebagai sebuah disiplin ilmu yang divisualisasikan adalah sebuah bukti sintesis dan persinggungan antara historiografi, ilmu komunikasi dan media, juga sosiologi.

\section{Tidak Lagi Militer Sentris}

Historiografi visual yang disajikan oleh pemerintah Orde Baru lewat medium film sangat kental akan heroisme pihak militer. Film-film seperti Janur Kuning (1982) dan Serangan Fajar (1979) menjadi kultus sosok Soeharto sebagai pemimpin dari serangkaian aksi heroik seeprti Serangan Umum 1 Maret. Dua film ini bahkan masuk daftar wajib tonton bagi generasi yang hidup dan tumbuh kembang pada masa kekuasaan Orde Baru.

Orde Baru gemar sekali menggunakan dalih Serangan Umum 1 Maret sebagai alat legitimasi kekuasaan, sekaligus ikon pertunjukkan heroisme militer. Pada saat yang sama, serangan besar-besaran nan bersejarah ini juga mengisyaratkan lemahnya posisi sipil dalam menangani situasi negara yang genting (Irawanto, 1999, h. 62). Semenjak itu, terlebih lagi pasca kejadian berdarah 1965, militer mengambil semua otoritas tafsir sejarah. Tidak ada kesempatan bagi para sineas untuk membuat film yang berkisar pada perjuangan revolusi Indonesia menggunakan sudut pandang dan kronologi yang berbeda di luar heroisme kaum lorengloreng.
Memasuki era reformasi, historiografi yang dihadirkan secara visual mengalami pergeseran sudut pandang dan peran. Dominasi film-film yang menonjolkan heroisme kaum loreng-loreng mulai berkurang. Periode pendudukan Jepang hingga agresi militer Belanda direpresentasikan dalam beragam sudut pandang dan tidak melulu berorientasi pada pertempuran fisik yang diwakili oleh kaum militer semata. Riset tentang historiografi visual yang berfokus pada biopic Soegijapranata dan Hasyim Asy'ari menunjukkan fakta bahwa terdapat pergeseran historiografi visual di era revolusi fisik yang semula militer sentris, menjadi sipil sentris (Allifiansyah,2016).

Film Soegjia (2013) dan Sang Kiai (2013) menjadi bukti bergesernya kecederungan visualisasi era revolusi fisik yang semula sangat militer sentris, menjadi lebih sipil sentris. Film Soegjia (2012) berhasil mencuplik jasa dan perjuangan jemaat gereja yang bahu membahu angkat senjata melancarkan serang Umum 1 Maret di Yogyakarta. Sebuah serangan yang pada saat zaman Orde Baru diklaim militer sebagai one man show milik mereka. Sedangkan film Sang Kiai (2013) merepresentasikan entitas yang jauh lebih kompleks, yakni peran para santri yang terdiri dari masyarakat religius kelas bawah yang berjuang hingga titik darah penghabisan pada peristiwa Pertempuran Surabaya.

Dua film tersebut dianalisis menggunakan analisis naratology dari Greimas (1966, 1972) yang diturunkan aktan-aktannya berdasar pada logika silogisme (Budniakiewicz, 1992) yang dibedah dalam hitungan adegan per adegan. Metode Neo-Greimasian ini digunakan agar lepas dari tradisi strukturalis yang ketat dalam naratology Greimas. Dengan menggunakan sintesis antara tradisi naratologi dengan silogisme matematika, kita bisa menemukan unsur-unsur mikroskopik dalam struktur historiografi visual.

Dikajinya film sebagai salah satu medium untuk memahami historiografi didasari pada fakta bahwa masyarakat kini telah memahami realitas lewat layar-layar 
visual. Tingginya penggunaan medium televisi dan telepon genggam di Indonesia menjadi bukti bahwa kini realitas sudah dikemas lewat kanal-kanal visual. Pemahaman kita akan masa lalu juga mau tak mau telah termediasi menjadi wujud visual.

Tak hanya film, historiografi visual sejatinya juga muncul dalam serial-serial televisi seperti "Melawan Lupa", "Memoar", "Indonesia Mengingat" dan lain sebagainya. Menarik untuk dikaji soal narasi, wacana dan framing yang dihadirkan serial-serial bertema kesejarahan tersebut mengenai tokoh atau peristiwa di masa lalu. Aspekaspek seperti peristiwa apa saja yang diungkap, bagaimana alur narasinya, pemilihan gambar

\section{Mengkonsumsi Masa Lalu}

Salah satu ciri dari tradisi posmoderen adalah mencairnya relasi produksi dan konsumsi, juga pemaknaan terhadapnya (Rosenau, 1992, h. 37). Teks dan relasi-relasi sosial yang ada di dalamnya adalah kesatuan dari relasi produksi dan konsumsi yang lahir dari hubungan antar subjek-subjek yang sifatnya horizontal. Tidak ada lagi titik absolut saat sebuah subjek selalu menjadi produsen, sementara subjek yang lain selalu menjadi konsumen. Peran sebagai produsen dan konsumen teks akan dijalani masyarakat secara bergantian. Mereka bisa menjadi produsen sekalgus konsumen secara bersamaan.

Memasuki era reformasi, teks sejarah tidak lagi dianggap sebagai narasi mewah yang hanya bisa disentuh oleh penguasa ataupun otoritas ilmiah yang kerap menyebut diri mereka sebagai sejarawan. Keith Jenkins (2003, h. 38) berpendapat bahwa sejarawan bekerja berdasarkan ilusi dan imajinasi mereka tentang masa lalu yang mereka interpretasikan sedemikian rupa sehingga membentuk wacana publik dalam memahami apa yang terjadi di masa lampau.

Pendapat Jenkins ini menjadi pintu masuk bagi para pemerhati sejarah, baik yang berprofesi sebagai sejarawan maupun di luar profesi tersebut untuk menulis sejarah seluas-luasnya dengan beragam sudut pandang, tanpa terikat metode yang ketat. Dengan munculnya beragam media mulai dari koran, majalah, radio, televisi, hingga internet, sejarah mulai ditulis ulang dan menjadi bagian dari budaya populer yang dikonsumsi secara massal (Groot, 2008, h. 1). Teks sejarah menjadi narasi yang terbuka dengan hadirnya media sebagai sarana untuk menyampaikan fragmen-fragmen peristiwa sejarah. Terbukanya peluang industri media populer dalam menarasikan ulang narasi sejarah, menjadikan wacana dan metode yang digunakan untuk membedah sebuah peristiwa di masa lalu menjadi tidak absolut.

Sejarah kini tak lagi tampil dalam sajian berupa prasasti, daun lontar, kitab kuno, ataupun lembar-lembar jurnal ilmiah yang ditulis oleh akademisi yang bekerja untuk universitas atau institusi ilmiah lainnya. Kini, pergeseran metode penulisan sejarah berbasis visual atau yang disebut Alun Munslow sebagai 'visual turn' (Groot, 2008:2) menekankan pada liberalisasi historiografi. Kesejarahan melakukan artikulasi dengan sendirinya melalui tangantangan media massa populer seperti novel, film, dokumenter, sinema, artikel majalah, dan lain sebagainya. Komersialisasi sejarah sebagai entitas masa lalu, dipandang dalam dua sisi. Pertama, sejarah menjadi tidak objektif, simpang siur, dan rentan untuk terjadi fiksionalisasi fakta sejarah. Kedua, tafsir sejarah menjadi plural sehingga tidak ada lagi monopoli makna dan penafsiran. Segala tafsir dan metode penulisan yang digunakan akan selalu mengalami perdebatan dan dialektika yang tidak ada habisnya, sehingga berbuah progres dari kesejarahan itu sendiri sebagai sebuah refleksi.

Satu lagi hal yang menjadi perhatian saat memproduksi sejarah ke dalam sebuah produk budaya populer adalah faktor hiburan atau kemampuannya untuk menghibur (Culpeper, 2005). Sejarah yang dihadirkan kembali harus bersifat menghibur atau memberikan efek penarasan (curious). Contoh paling baik terkait hal ini adalah kuis yang menyertakan pertanyaan-pertanyaan menyangkut kesejarahan dan bersifat trivia yang bahkan jarang diketahui oleh publik secara luas. Taktik semacam ini adalah bagian dari cara budaya populer untuk menghibur dengan menggunakan narasi sejarah (historical knowledge). 
Teks sejarah yang tersaji dalam film
populer, menggunakan prinsip posmodernisme. Hal didasari fakta bahwa teks sejarah yang kita saksikan melalui televisi, majalah, koran, film, maupun novel, ingin lepas dari kaidah ilmiah yang serba terstandar dan kaku (Storey, 2008:182). Prinsip ini tentunya diikuti oleh penulisan historiografi yang kian beragam dan mengalami pembaharuan. Sejarah kini mulai dilirik sebagai produk yang seksi untuk dibicarakan ulang dan tertuang melalui beragam media, mulai dari konvensional, online, tertulis, mapun visual. Kecenderungan ini juga mengubah pemahaman kita terhadap sejarah publik (public history) menjadi applied history, yang tentunya akan memperkaya metode sekaligus mencoba keluar dari sudut pandang dan penulisan sejarah yang biasanya dilakukan sejarawan akademis secara ketat (Brahmantyo, 2016). Dengan ini berarti sejarah mengalami popularisasi hingga sanggup dijangkau sekaligus ditulis ulang oleh siapa saja dengan beragam argumen, metode, dan perspektif.

\section{PENUTUP \& SIMPULAN}

Semangat lahirnya tradisi pemikiran posmoderen selalu berawal dari keinginan untuk lepas dari belenggu moderenitas yang serba kaku dan terstandar. Salah satu hasil dari semangat pergeseran paradigma moderen menjadi posmoderen tercermin dalam penulisan historiografi yang kini terwujud secara visual. Medium film biopic populer menjadi salah satu wadah untuk menulis ulang historiografi Indonesia.

Liberalisasi penulisan historiografi ini menjadi terobosan era Refomasi setelah puluhan tahun historiografi Indonesia begitu militer-sentris. Istilah visual historiografi yang menonjolkan pada aspek semiotik dan representasi sejarah yang ditubuhkan menuai pro dan kontra. Dengan visualisasi, sejarah menjadi teks yang terbuka sehingga memungkinkan adanya tafsir yang plural. Akan tetapi di sisi yang lain, sejarah yang telah mengalami visualisasi menyisakan pertanyaan perihal akurasi dan adanya distorsi fakta masa lalu.
Perdebatan soal subjektifitas ini sebenarnya sudah terjadi bahkan sebelum sejarah mengalami visualisasi dan masuk dalam medium populer seperti film dan televisi. Dengan hadirnya historiografi visual dalam indsutri budaya populer, memungkinkan pula terjadinya perluasan pengetahuan akan satu tokoh. Tokoh-tokoh agama tertentu yang semula hanya dipelajari secara terbatas dalam kalangan umatnya sendiri, menjadi tokoh yang dipelajari oleh masyarakat luas setelah kisah hidupnya diangkat ke layar lebar.

Sejarah kini dikonsumsi, tidak lagi dipelajari secara tertutup. Medium populer seperti film dan televisi menjual romantisme dan heroisme masa lalu sehingga menarik untuk dikonsumsi berbagai kalangan. Hadirnya aktor dan aktris populer akan menambah daya tarik dari sebuah historiografi yang ditubuhkan ke dalam layar-layar visual bergerak.

\section{DAFTAR PUSTAKA}

Alian. (2012). Metodologi Sejarah dan Implementasi dalam Penelitian. Palembang: Universitas Sriwijaya.

Allifiansyah, Sandy. (2016). Agama, Film, dan Revolusi: Historiografi Visual Dua Tokoh Otoritas Agama saat periode Pendudukan Jepang hingga Revolusi Nasional dalam Film Soegija (2012) dan Sang Kiai (2013). Tesis Master pada Universitas Gadjah Mada Yogyakarta.

Batchen, G. (1996). Spectres of Cyberspace. Artlink Vol 16 (2 \& 3), 25-28.

Barker, Chris. (2004). The SAGE Dictionary of Cultural Studies. London: SAGE.

Beau, B. F. (1997). Historiography Meets Historiopothy: The Peril and Promise of Rendering The Past on Film. American Studies Vol 38 (1), 151-155.

Birchall, Clare. (2006). Knowledge Goes Pop: From Conspiracy Theory to Gossip. Oxford: Berg.

Brahmantyo, K. (2016). Sejarah Publik dan Agen Perubahan. Jakarta: Koran Tempo 29 Januari 2016.

Budniakiewicz, T. (1992). Fundamentals of Story Logic: Introduction to Greimassian Semiotics. John 
Benjamins Publishing Company: Amsterdam/Philadelphia.

Culpeper, J. (2005). Impoliteness and Entertainment in The Television Quiz Show: The Weakest Link. Journal of Politeness Research Vol 1, 35-72.

Custen, George F. (1992). Bio/Pics: How Hollywood Constructed Public History. New Brunswick: Rutgers University Press.

Deliege, R. (2004). Levi-Staruss Today: An Introduction to Structural Antrophology. New York: Berg.

Greimas, J. A. (1966). Structural Sematics. Lincoln: University of Nebraska Press.

$$
\text { (1972). Semantique }
$$

Strukturale. Paris: Larousse.

Groot, Jerome. de. (2008). Consuming History: Historians and Heritage in Contemporary Popular Culture. New York: Routledge.

Hesling, Willem. (2001). The Past as Story; The Narrative Structure of Histrorical Films. European Journal of Cultural Studies Vol 4 (2), 189-205.

Irawanto, Budi. (1999). Film, Ideologi, dan Militer: Hegemoni Militer dalam Sinema Indonesia. Yogyakarta: Media Pressindo.

Jenkins, Keith. (2003). Refiguring History. London: Routledge.

Kartodirdjo, S. (1983). Pendekatan Ilmu Sosial Dalam Metodologi Sejarah. Jakarta: Gramedia Pustaka Utama.

Kuntowijoyo. (2003). Metodologi Sejarah. Yogyakarta: Tiara Wacana.
Nugroho, G., \& Herlina, D. (2015). Krisis dan Paradoks Film Indonesia. Jakarta: Kompas Gramedia.

Rojek, Cris. (2001). Celebrity. London: Reaktion.

Rosenau, Pauline Marie. (1992). PostModerenism and The Social Sciences: Insight, Inroads, and Intrusions. New Jersey: Princeton University Press

Rosenstone, Robert. A. (2002). Does a Filmic Writing of History Exist?. History and Theory Vol 41 (4), 134144.

Seidman, S. (1994). Introduction Posmoderenismism. In S. Seidman, The Posmoderenism Turn: New Perspective on Social Theory (pp. 123). Cambridge: Cambridge University Press.

Storey, John. (2008). Cultural Theory and Popular Culture. Sunderland: Pearson.

White, Hayden. (1974). Metahistory: The Historical Imagination in NineteenthCentury Europe. Baltimore: John Hopkins University Press. .(1988). Historiography and Historiopothy. The American Historical Review Vol. 93 (5), 11931199.

Zed, M. (2001). Menggugat Tirani Sejarah Nasional Suatu Telaah Pendahuluan Tentang Wacana Sejarah Nasional Dalam Perspektif Perbandingan. Disampaikan Dalam Konfrensi Nasional Sejarah Indonesia VII, (p. 3). Jakarta. 